\title{
Marine interstitial Amphipoda and Isopoda (Crustacea) from Santiago, Cape Verde Islands
}

\author{
Jan H. Stock \& Ronald Vonk \\ Institute of Taxonomic Zoology, University of Amsterdam, P.O. Box 4766, 1009 AT Amsterdam, \\ The Netherlands
}

Keywords: Amphipoda, Isopoda, interstitial, Cape Verde Islands

\begin{abstract}
Three species of Amphipoda are recorded from interstices of a marine beach on the island of Santiago, Cape Verde Archipelago: Cabogidiella littoralis n. gen., n. sp. (Bogidiellidae), Psammogammarus spinosus n. sp. (Melitidae), and Idunella sketi Karaman, 1980 (Liljeborgiidae). The latter, widely distributed species (West Indies, Canary Islands), is new to the Cape Verde Islands. Furthermore, an isopod is described from the same locality, Caecostenetroides mixtum n. sp. (Gnathostenetroididae).
\end{abstract}

\section{Résumé}

Trois espèces d'Amphipodes sont signalées d'interstices d'une plage marine sur l'île de Santiago, archipel du Cap-Vert: Cabogidiella littoralis gen. et sp. nov. (Bogidiellidae), Psammogammarus spinosus sp. nov. (Melitidae) et Idunella sketi Karaman, 1980 (Liljeborgiidae). La dernière, une espèce largement répandue (Indes occidentales, îles Canaries), est nouvelle pour les îles du Cap-Vert. Également décrit de la même localité, est un Isopode, Caecostenetroides mixtum sp. nov. (Gnathostenetroididae).

\section{Introduction}

In the frame of a study on the stygofauna of the mid-Atlantic islands, a visit was paid to two islands of the Cape Verde Archipelago. The present paper describes a number of malacostracan crustaceans found in interstitial waters of a marine beach on the island of Santiago. Previous to our studies, no stygofaunal crustaceans were known from this island.

\author{
Material and methods
}

The material on which this paper is based has been collected with a Bou-Rouch biophreatical pump (see Bou, 1975), on a tidal beach flat on the island of Santiago in the Cape Verde Archipelago, at a depth of some $50 \mathrm{~cm}$ below the substrate surface, at several places between low-tide and a zone rather high in the mediolittoral belt. The sediments in which the animals lived consisted of a mixture of gravel, coarse sand, and some silt. At the moment of sampling, the salinity was the same as in the open sea, but - because the beach in question is situated in the mouth of a temporarily dry torrent which carries water only during exceptional showers - an occasional decrease in salinity is possible.

\section{Taxonomic part}

AMPHIPODA

Family Bogidiellidae

\section{Cabogidiella n. gen.}

Diagnosis. - Bogidiellidae with 5 pairs of coxal gills (on pereionites 2 through 6). Molar part of mandible in reduction. Palp of first maxilla 2-segmented. Pleopodal exopodites 3-segmented, not sexually dimorphic; endopodite absent. Uropod 1: both rami of both sexes modified into dagger-like structures. Rami of uropod 3 subequal in length.

The genus is monotypic; type-species $C$. littoralis n. sp. 
Derivatio nominis. - The generic name is a contraction of the terra typica, the Cape Verde Islands, and the name of the type-genus of the family Bogidiellidae. The specific name refers to the intertidal habitat.

Remarks. - Within the family Bogidiellidae (sensu Stock, 1981, and Coineau \& Stock, 1986), there are several (sub)genera that share the transformation of one or both rami of uropod 1 into more or less dagger-shaped structures: (1) Pseudingolfiella Noodt, 1965; (2) Dussartiella Ruffo, 1979; (3) Kerguelenella Ruffo, 1974; (4) Bollegidia Ruffo, 1974; (5) Antillogidiella Stock, 1981; (6) Actogidiella Stock, 1981; (7) Marigidiella Stock, 1981; (8) Marinogidiella Karaman, 1982*; (9) Cabogidiella n. gen.; and perhaps (10) Aurobogidiella Karaman, 1988. Most of these genera share the same type of habitat, viz. marine intertidal or sublittoral sands. Only Dussartiella comes from a freshwater spring and Antillogidiella has been found in a brackish well and in an anchihaline cave.

Of these genera, $\mathrm{nr}$. 1 is characterized by an apomorphic (uniramous) uropod 3. Nr. 2 has an apomorphic (reduced) mandible palp, a parviramous uropod 3, and a plesiomorphic (multisegmented) exopodite in the pleopods. Nr. 3 is, amongst other characters, characterized by apomorphic (unisegmented) rami of the pleopods. $\mathrm{Nr} .4$ possesses an apomorphic (uniramous) uropod 1. The remaining genera, nrs. 5 through 10 , belong to the cluster around the genus Bogidiella.

Of these, nr. 10 possesses, according to Karaman's (1988) Fig. 1J, a dagger-shaped endopodite in uropod 1, but in his text (: 101) this shape is dismissed as due to previous damage. The exopodite of uropod 1 in this genus is more or less plesiomorphic, in that it bears some distal spines. Aurobogidiella differs moreover from Cabogidiella in the plesiomorphic 4-segmented exopodites of pleopods 1 and 2 (versus 3-segmented), the absence of a coxal gill on pereionite 2 (versus presence), and a less reduced mandible (with spine row between incisor and molar).

\footnotetext{
* As to the date of publication of Karaman's paper, see Coineau \& Stock, 1986: 580.
}

Genera nrs. 7 and 8 differ from Cabogidiella in an apomorphic, 1-segmented palp of maxilla 1 (versus 2-segmented), and in "special" pleopods (third exopodite segment minute or absent; endopodite at least as long as first exopodite segment).

No doubt, the new genus Cabogidiella is closest to Antillogidiella (nr. 5) and Actogidiella (nr. 6), both endemic to the West Indian area sensu lato. The latter two differ (1) in having coxal gills on pereionites 4 through 6 only (on 2 through 6 in the new genus); (2) in lacking a dagger-like modification in the rami of uropod 1 of the male (although those of the female are modified as in both sexes of Cabogidiella); and (3) in showing sexual dimorphism in pleopod 2 (none in the new genus).

As is usual in the Bogidiellidae, the (sub)genera are characterized by a combination of apomorphic and plesiomorphic characters of a rather refined nature. In Cabogidiella, the absence of sexual dimorphism in the pleopods and the high number of coxal gills (5 pairs) are plesiomorphic, but the modified uropod 1 in both male and female and the reduced molar part of the mandible are apomorphic.

\section{Cabogidiella littoralis $\mathrm{n}$. sp.}

(Figs. 1-2)

Material. - All from the intertidal zone of a beach in the mouth of a dry riverbed, S.W. of Achada de Santo Antonio (island of Santiago, S.W. of Praia); UTM coordinates TS $22785 \times$ 164885; 31 Jan. 1991.

Sta. 91-24: $1 \sigma$ (holotype), $1 \odot$ (allotype), 89 paratypes, in a bank of fine gravel at mid-tide (Zoölogisch Museum Amsterdam, ZMA Coll. Nr. Amph. 108.832).

Sta. 91-21: 1 paratype, in a tidal pool filled with sand and gravel, at mid-tide (ZMA Amph. 108.835).

Sta. 91-22: 11 paratypes, in a creek with sandy bottom, below the mid-tide level (ZMA Amph. 108.833).

Sta. 91-23: 12 paratypes, near the low-tide line, in rather fine sand (ZMA Amph. 108.834).

Accompanying interstitial fauna: Caecostenetroides mixtum n. sp. (lsopoda), Psammogammarus spinosus n. sp., Dulzura lobata Stock \& Vonk, 1991, Idunella sketi Karaman, 1980 (Amphipoda), and Staurocladia sp. (Hydrozoa).

Description. - Small-sized species (body length 1.13-1.49 mm, $n=10$ ); males tend to be slightly smaller than females. Body shape as typical of the 

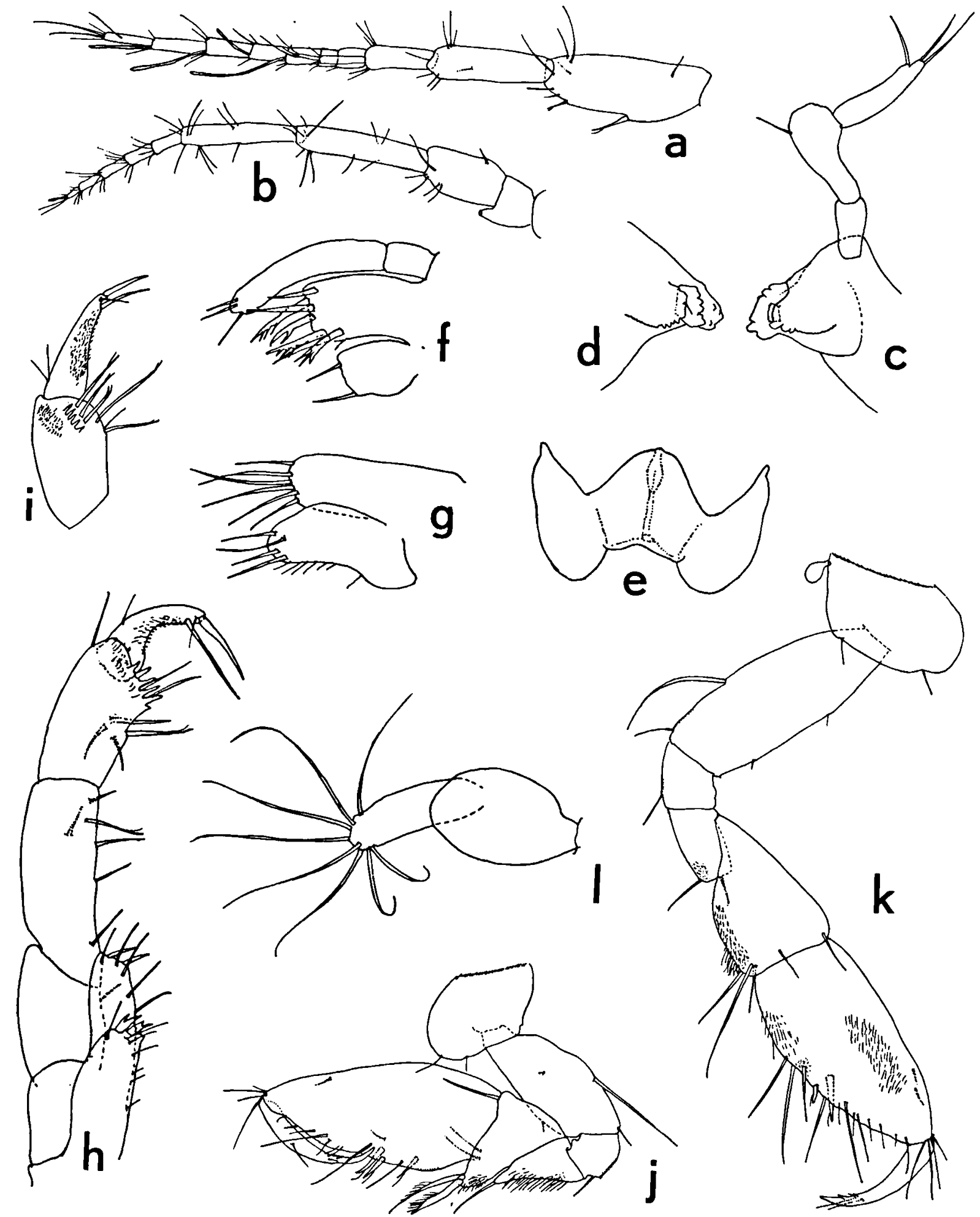

Fig. 1. Cabogidiella littoralis $\mathrm{n}$. gen., n. sp., paratypes: a, antenna 1, ९ (scale A); b, antenna 2, ९ (A); c, right mandible, ९ (D); d, left corpus mandibulae, $Q$ (D); e, labium, Q (E); f, maxilla 1, $\odot$ (D); g, maxilla 2, Q (D); h, maxilliped, $\sigma$ (D); i, tip of maxillipedal palp, $\sigma^{\circ}$, seen from a different angle (B); j, gnathopod $1, \sigma^{\circ}(\mathrm{C}) ; \mathrm{k}$, gnathopod $2, \sigma^{\circ}(\mathrm{C}) ; 1$, coxal gill and oostegite of pereiopod 5 , (C). Scales on Fig. 2. 
Bogidiella-group; blind, colourless.

Antenna 1 (Fig. 1a) with 2 spines on ventral margin of peduncle segment 1 ; segment 2 about $75 \%$ of length of segment 1; segment 3 more than $50 \%$ of length of segment 2. Accessory flagellum 2-segmented, long. Flagellum 7-segmented; long aesthetascs on segments 3 through 6 .

Antenna 2 (Fig. 1b) with short, plump gland cone. Flagellum 5-segmented; 1 short aesthetasc on segment 5 .

Mandibles (Figs. 1c, d): Incisor short, robust, teeth poorly developed. Right lacinia mobilis finely denticulate; left lacinia vaguely 5- or 6-dentate. Molar reduced in size; left molar with minute seta, right molar without seta. Palp 3-segmented; segment 2 distally swollen, with 1 seta; segment 3 narrower than segment 2, with 3 (sub)distal setae.

Labium (Fig. 1e) with well-developed outer lobes; inner lobes probably represented by almost straight stretch between outer lobes.

Maxilla 1 (Fig. 1f) with 2-segmented palp; palp segment 2 with 3 distal setae. Outer lobe with 7 distal spines; inner margin of these spines, from lateral to medial, armed with 0-3-0-1-3-0-3 denticles. Inner lobe with truncate distal margin, armed with 2 setae.

Maxilla 2 (Fig. 1g) with 6 setae on outer lobe and 4 on inner lobe.

Maxilliped (Figs. 1h, i): Inner and outer plates short; inner plate distally with 2 simple teeth; outer plate distally with 2 simple spines. Palp segment 3 with row of 5 teeth and 6 medial setae. Shape of segments 3 and 4 show up differently when seen from different angles (see illustrations). Segment 4 (dactylus) more or less strongly curved, distally with 3 elements (2 long, 1 short).

Coxal plates small, wider than long, not overlapping.

Gnathopod (Fig. 1j): Basis with 1 long seta on posterior margin. Merus with finger-shaped distoposterior projection, armed with 1 seta. Carpus with broad, rounded posterior projection, armed with 1 barbed spine and 1 barbed seta. Propodus elongate-ovate; 2 palmar angle spines; palmar margin convex, with 2 long setae and some small setules. Dactylus curved.

Gnathopod 2 (Fig. 1k) longer than gnathopod 1.
Basis with 1 long seta on posterior margin. Propodus of same size as that of gnathopod 1, elongateovate; 2 palmar angle spines; palmar margin with setae only.

Pereiopods 3 (Fig. 2a) and 4 of similar morphology, very poorly armed. Pereiopod 5 (Fig. 2b) slightly longer than pereiopod 4, poorly armed. Pereiopod 6 as long as pereiopod 5 and of similar morphology. Pereiopod 7 (Fig. 2c) longer and more robust than pereiopod 6 and more strongly armed, with some long setae on distal end of carpus and some very long setae on anterior margin of propodus. Claw very long, about $60 \%$ of length of propodus. No lentiform organs on pereiopods 3 to 7 .

Coxal gills on pereionites 2 through 6 , ovate with poorly demarcated basal stalk; very small (not extending beyond ventral margin of coxal plate) on pereionite 2, small (but extending beyond coxal plate) on remaining pereionites (Fig. 11). Oostegites on pereionites 2 through 5 , short, linear, in distal part armed with some 8 long setae, which are about as long as oostegite (Fig. 11).

Epimeral plates (Fig. 2d) with convex, naked ventral margin. Posteroventral corner notched, with 1 setule, in plates 1 and 2; rounded, without setule, in plate 3 .

Pleopods 1 to 3 of similar general morphology (Figs. 2e-g), but decreasing in length in anteroposterior direction. Peduncle with 2 retinacula. Exopodite segment 1 with 2 short plumose setae; segment 2 with 2 medium-sized plumose setae; segment 3 long and slender, with 2 long plumose setae. Endopodite absent.

Uropod 1 (Fig. 2h): Peduncle without ventroproximal spine and without dorsal spines; distal spines small. Exopodite much shorter than endopodite, upcurved, dagger-shaped, armed with 1 setule at about $60 \%$ of its length. Endopodite likewise upcurved and dagger-shaped, with 1 setule slightly proximad of middle of segment.

Uropod 2 (Fig. 2i) normal. Peduncle with 2 distal spines only. Exopodite slightly shorter than endopodite, both with short distal spines only.

Uropod 3 (Fig. 2j): Peduncle and rami armed with very long spines. Rami of equal length. Exopodite usually with group of central spines (number of spines may vary between 0 and 4), endopodite with 


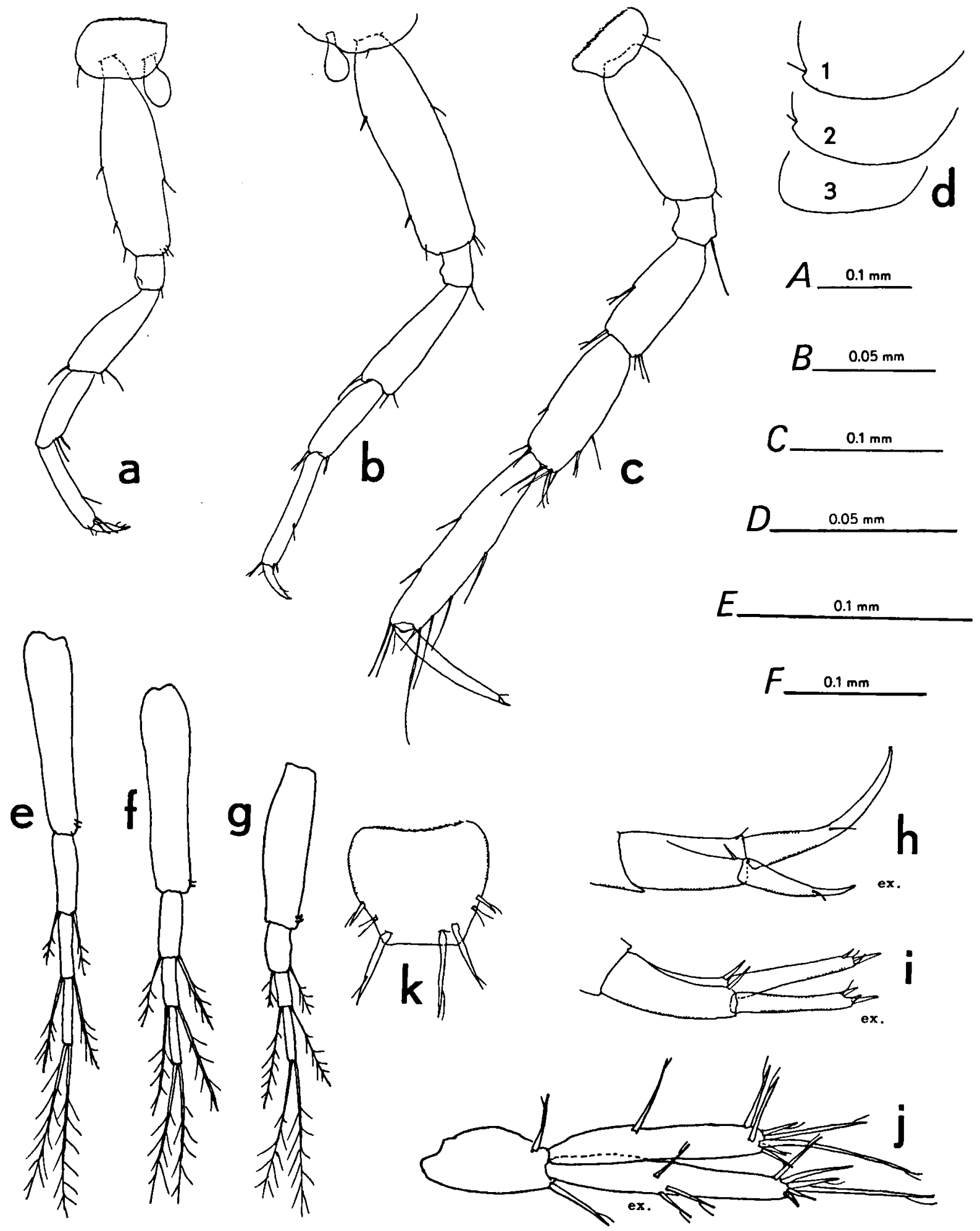

Fig. 2. Cabogidiella littoralis n. gen., n. sp., paratypes: a, pereiopod 3, ᄋ (scale A); b, pereiopod 5, ᄋ (A); c, pereiopod 7, Ơ (A);

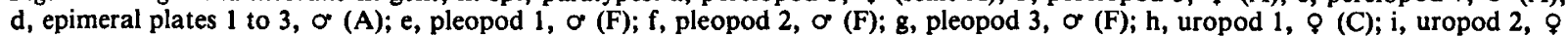
(C); j, uropod 3, \& (F); k, telson, \& (B). [ex. = exopodite.] 
1 spine near middle of medial margin.

Telson (Fig. 2k) roughly trapezoidal; distal margin almost straight; 1 or 2 long distolateral spines, 1 short spine and 2 sensory setules on lateral margin.

No sexual differences observed in pereional, pleonal, or urosomal appendages.

Remarks. - Although a large number of specimens is available, not a single specimen is complete: the posterior pereiopods and the third uropod are very often lacking. In the above description a combination is made of the appendages of several paratypes.

Family Melitidae

Genus Psammogammarus S. Karaman, 1955

Psammogammarus spinosus n. sp.

(Figs. 3-6)

Material. - Sta. 91-21: 1 o holotype, 8 paratypes (ZMA Amph. 108.828); sta. 91-22: 2 paratypes (ZMA Amph. 108.830); sta. 91-23: 1 ९ allotype, 2 paratypes (ZMA Amph. 108.829); sta. 91-24: 14 paratypes (ZMA Amph. 108.831). For more details about these stations, see above under Cabogidiella littoralis.

Description. - Body shape resembling that of $P s$. stocki Vonk, 1990. Coxal plates 1 to 4 touching or slightly overlapping, plates 5 to 7 not touching. Body length (without antennae and uropods) of adult male $2.6 \mathrm{~mm}$, of adult female $2.5 \mathrm{~mm}$. Ovigerous females with very few (1 to 3) large eggs. Blind. Body unpigmented. Dorsum armed with a few setules only. Lateral head lobe (Fig. 3a) pronounced, rounded; antennal sinus hardly indicated, unnotched. Epimeral plates (Fig. 3k) without ventral armature, weakly pointed.

Appendages of female: Antenna 1 (Fig. 3b) 1.7 $\mathrm{mm}$ long. Peduncle armed with setae only; peduncle segment $1>2>3$. Accessory flagellum about as long as proximal two flagellum segments combined, 2-segmented. Flagellum 13-segmented, aesthetascs on segments 3 through 12, thin, about $75 \%$ of length of corresponding flagellum segment.

Antenna 2 (Fig. 3c) much shorter than antenna 1. Gland cone distally truncate, rather short. Pedun- cle segments 4 and 5 of equal length, with some setae. Flagellum 7-segmented.

Labrum as illustrated (Fig. 3d); distal margin almost straight.

Left mandible (Fig. 3e) with 3-segmented palp, segment 3 short. Incisor 5-dentate. Lacinia mobilis 5-dentate; 5 pre-lacinia spines. Molar small, with short, plumose molar seta. Right mandible (Fig. 3f) as left one, but lacinia with 2 finely toothed cusps, and 4 pre-lacinia spines; molar likewise with seta.

Labium with distinct inner lobes (Fig. 3g).

Left maxilla 1 (Fig. 3h) with slender, narrow, 2-segmented palp, armed in distal part with 4 slender spines and 1 seta. Outer lobe with 7 spines, the medial margin of which (from lateral to medial) with 3-3-many-1-many-1-many denticles, respectively. Inner lobe roughly rectangular, with 1 short and 4 long setae. Palp of right maxilla 1 (Fig. 3i) much more robust than left, with 1 seta and 4 short spines.

Maxilla 2 (Fig. 3j) with oblique row of 4 strong setae on inner lobe.

Maxilliped (Fig. 4a): Palp segment 3 bulbous; claw long, curved. Outer lobe with 2 spines on distal margin and 2 on medial margin. Inner lobe with 3 small distal spine-teeth.

Gnathopod 1 (Fig. 4b) much smaller than gnathopod 2. Coxal plate much wider than long. Merus lobate. Carpus longer than wide, shorter than propodus. Propodus with 2 palmar angle spines; palmar margin convex, finely denticulate, with row of 8 small, partly bifid, spines. Claw curved.

Gnathopod 2 (Fig. 4d) with long, ribbon-shaped coxal gill. Coxal plate wider than long. Merus not lobate, but with small distoposterior point. Carpus triangular. Propodus elongate-ovate. Palmar margin convex, finely denticulate, with 7 small spines and 2 palmar angle spines. Claw thin, curved.

Pereiopods 3 (Fig. 5a) and 4 similar; coxal plate wider than long; coxal gill elongate ovate, nearly as long as basis. All segments sparsely setose.

Pereiopod 5 (Fig. 5b) much shorter than pereiopod 6. Coxal plate anterolobate, with somewhat club-shaped coxal gill, smaller than coxal gill of P3. Posterodistal corner of basis subangular; both anterior and posterior margin of basis almost straight. 


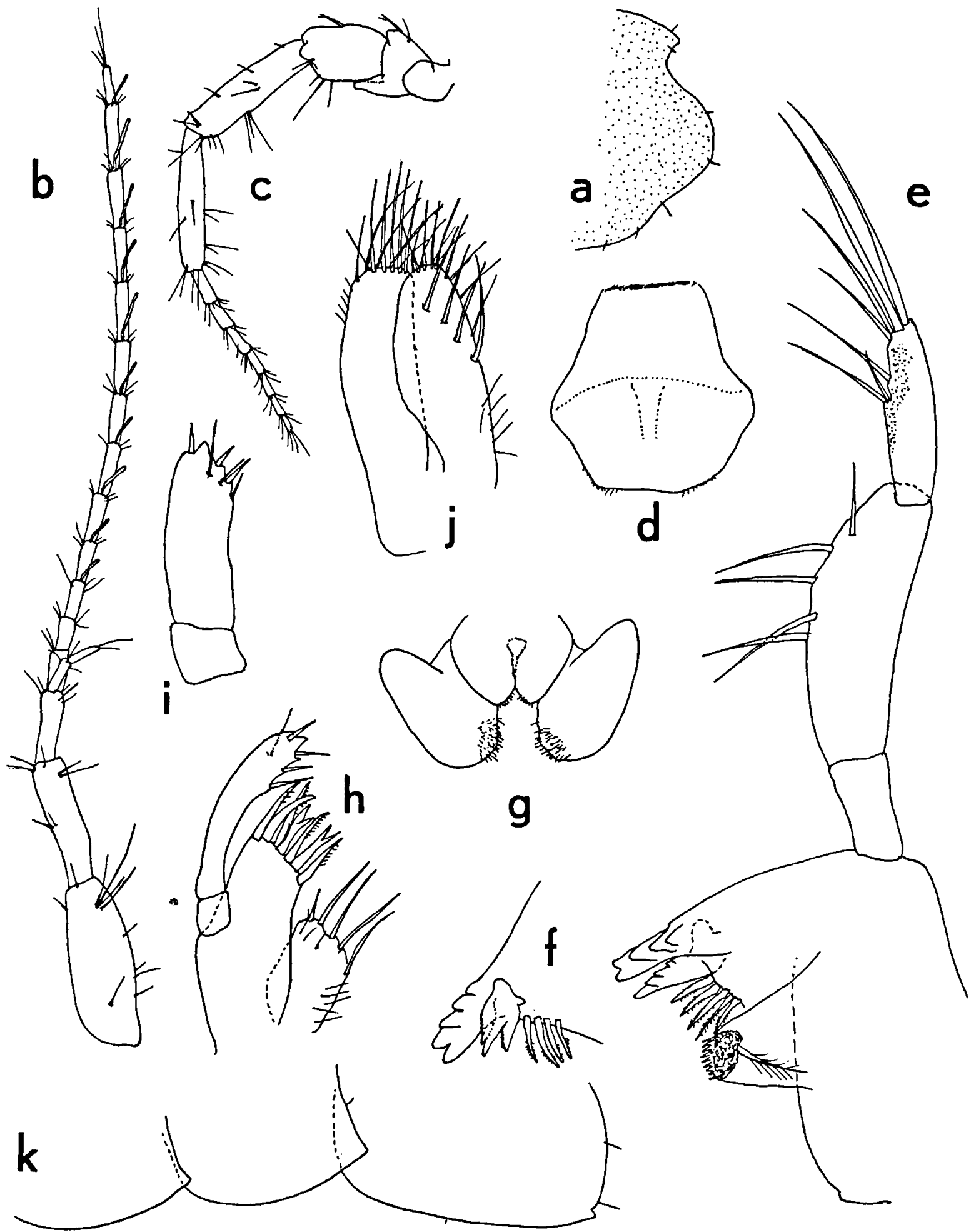

Fig. 3. Psammogammarus spinosus n. sp., paratypes: a, head, from the right, \& (scale G); b, antenna 1, ९ (H); c, antenna 2, ९ (H);

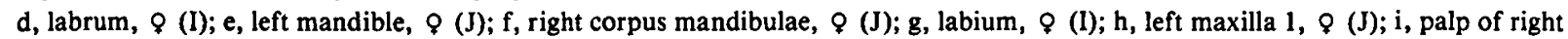
maxilla 1 , $9(\mathrm{~J})$; j, maxilla $2, \%(\mathrm{E})$; $\mathrm{k}$, epimeral plates 1 to $3, \sigma(\mathrm{G})$. Scales on Fig. 5. 


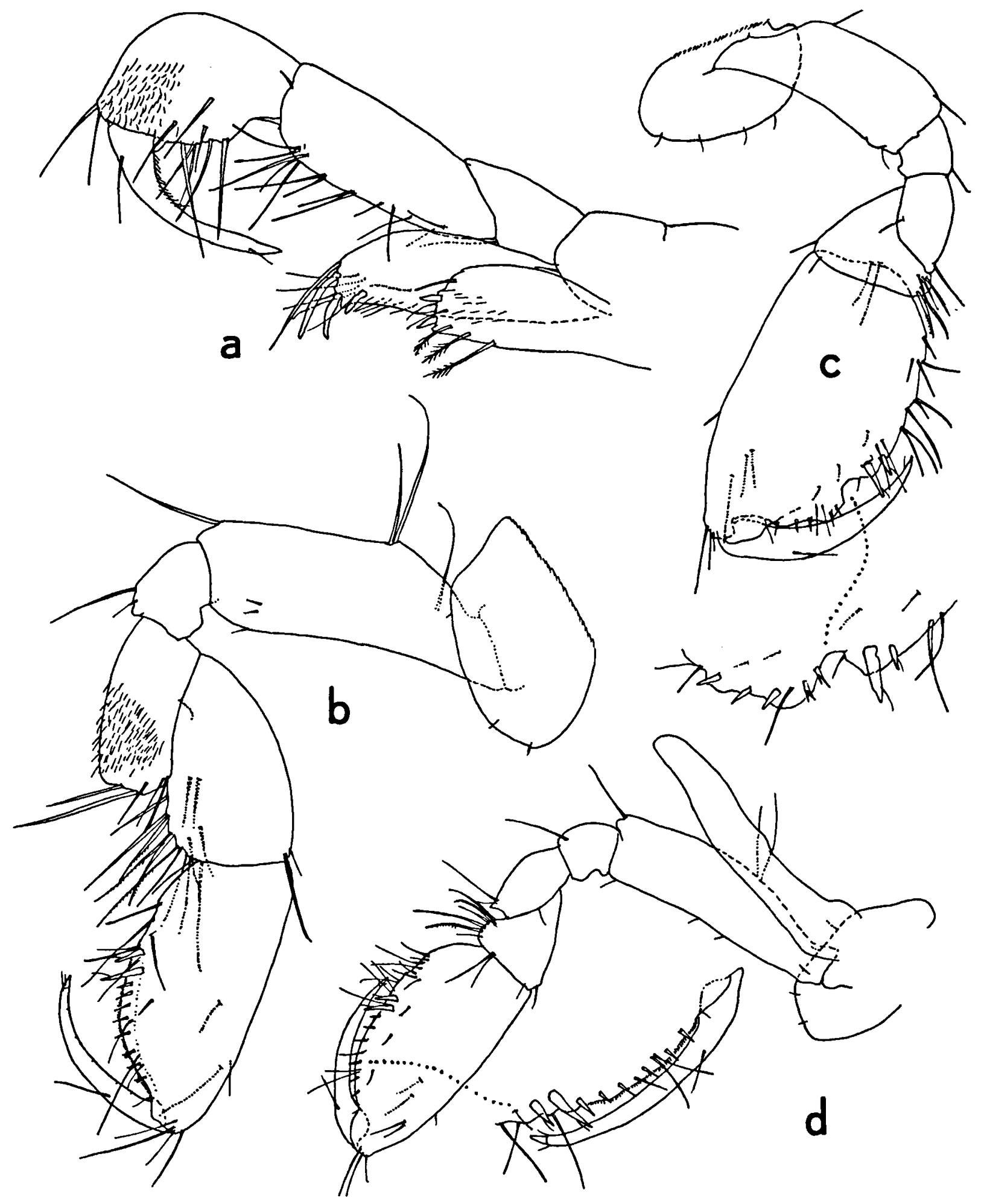

Fig. 4. Psammogammarus spinosus n. sp., paratypes: a, maxilliped, $\odot$ (scale J); b, gnathopod 1, ९ (J); c, gnathopod 2, $\sigma$ (G); d, gnathopod 2, ९ (G). Scales on Fig. 5. 


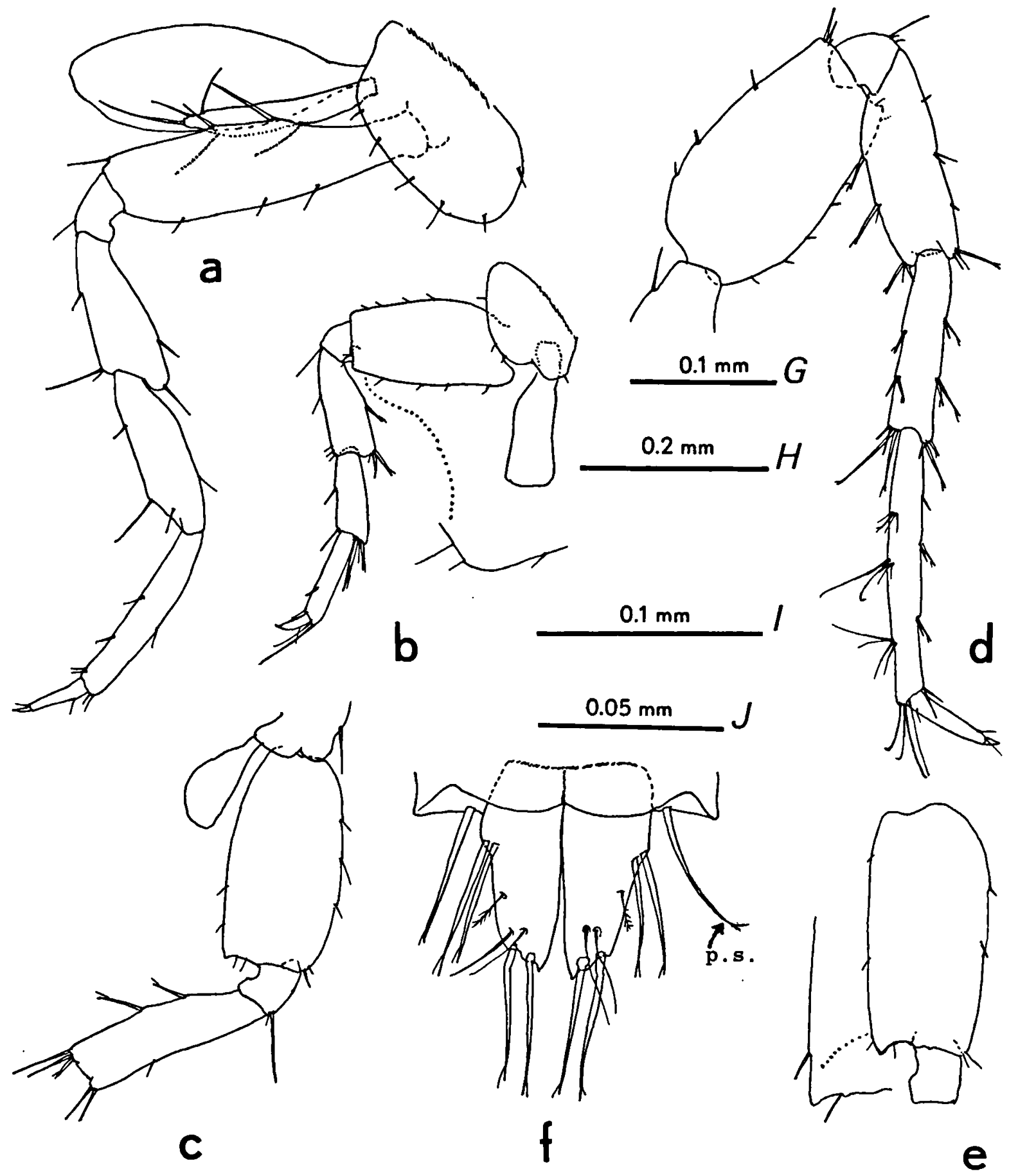

Fig. 5. Psammogammarus spinosus n. sp., paratypes: a, pereiopod 3, $९$ (scale G); b, pereiopod S, $\odot$ (H); c, basal part of pereiopod 6, $९$ (H); d, pereiopod 7, \& (H); e, basis of pereiopod 7, $\sigma^{\circ}(\mathrm{I})$; f, telson, $\&$ (I). [p.s. = prepeduncular spine of uropod 3.] 


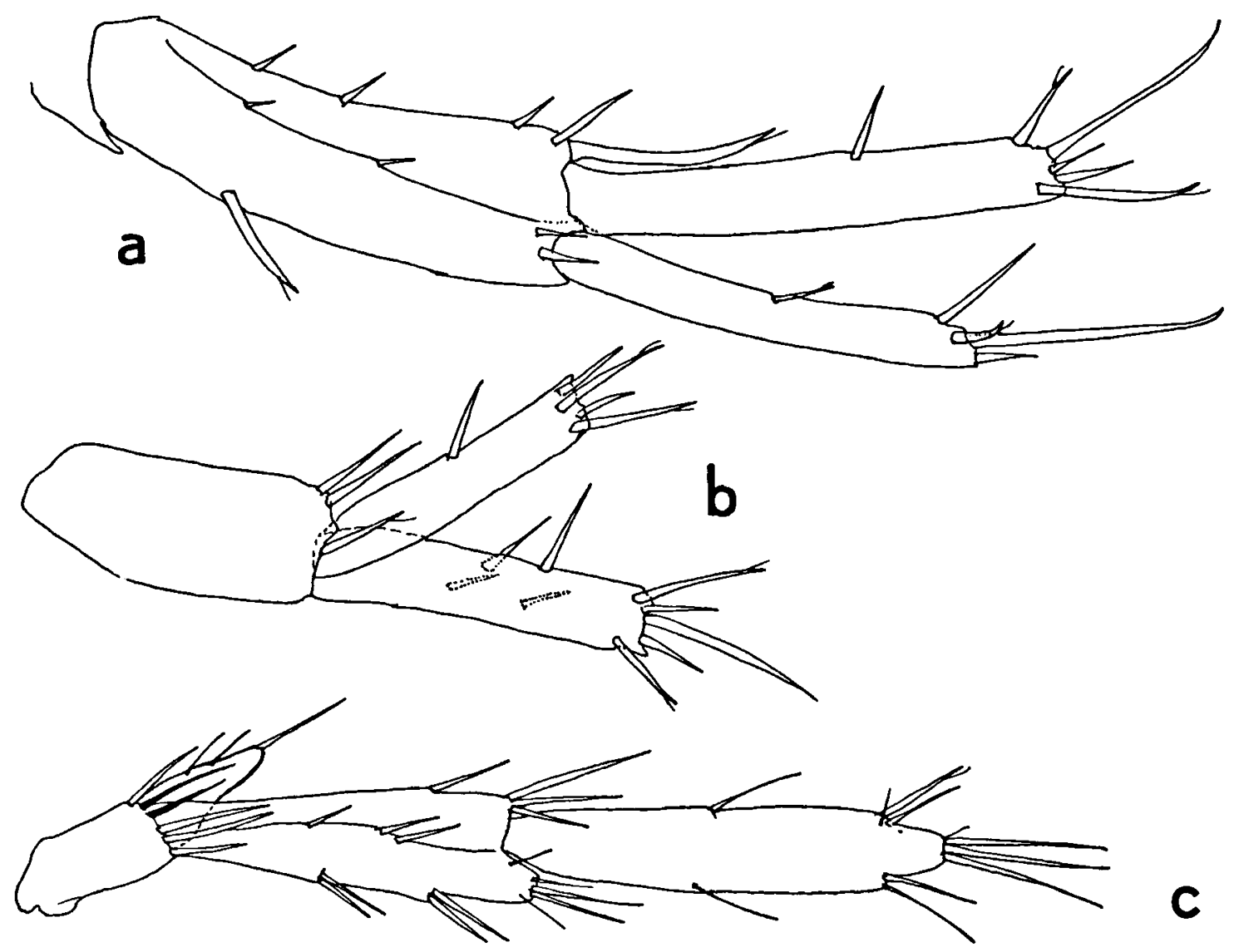

Fig. 6. Psammogammarus spinosus n. sp., paratypes: a, uropod 1, o (scale 1); b, uropod 2, ơ (I); c, uropod 3, ९ (I). Scales on Fig. 5.

Pereiopods 6 and 7 subequal in length. Pereiopod 6 (Fig. 5c) with equilobate, small coxal plate, bearing strong seta on anterior margin; coxal gill small. Margins of basis almost straight; posterodistal lobe angular. Pereiopod 7 (Fig. 5d) with small, non-lobate, rectangular coxal plate, bearing strong seta on anterior margin; no coxal gill. Basis with almost straight margins; posterodistal lobe pointed.

Oostegites (Fig. 5a) linear, on gnathopod 2 and pereiopods 3, 4, and 5; with few, long, marginal setae.

Pleopods 1 to 3 “ordinary". Endopodite longer than exopodite. Rami of first pleopod 7-segmented; of second and third pleopods 4- to 6-segmented. Two denticulate retinacula on peduncle.

Uropod 1 (Fig. 6a): Peduncle with strong ventroproximal spine; 2 laterodorsal spines; 4 mediodorsal spines; very long, slightly upcurved distodor- sal inner spine; 2 short distodorsal outer spines. Exopodite slightly shorter than endopodite, with 1 dorsal spine and 4 distal spines, one of which very long. Endopodite with 1 or 2 dorsal spines and 5 distal spines, of which 2 long.

Uropod 2 (Fig. 6b): Peduncle with 3 distal spines. Exopodite slightly shorter than endopodite, with 1 dorsal spine and 4 distal spines. Endopodite with 2 dorsal, 2 medial, and 5 distal spines.

Uropod 3 (Fig. 6c) with long, ventral, prepeduncular spine (p.s. in Fig. 5f). Peduncle with 6 long distal spines. Endopodite tapering, short, about as long as peduncle; with 1 distal seta and 2 short, medial setae. Exopodite segment 2 longer than segment 1 ; segment 1 armed mostly with spiniform elements, segment 2 mostly with setiform elements.

Telson (Fig. 5f) almost completely cleft; each lobe with 2 very long lateral spines in subproximal position (sometimes these 2 spines of very unequal 
length), 1 mediolateral, plumose setule, 2 very long distal spines, and 2 long, subdistal sensory setules.

Appendages of male. - Pronounced sexual dimorphism in gnathopod 2 (Fig. 4c) only: basis with 1 seta on posterior margin; propodus larger than in female and somewhat more swollen; palmar margin with distinct emargination just distad of the two angle spines and 2 (hardly separated) swellings in distal part.

No calceoli on antennae. No sexual dimorphism in pleopods. None of the males examined has retained the third uropod.

Etymology. - The specific name spinosus (Latin, spiny) alludes to the long telson spines.

Remarks. - Stock \& Sánchez (1987) have presented a key to the species of Psammogammarus s.l. In the years after 1987 two more species have been described in the genus, viz. Ps. stocki Vonk, 1990 and Ps. fluviatilis Stock, 1991. The former species keys out in couplet $3 \mathrm{~b}$ of the key, the latter in couplet $2 \mathrm{~b}$. The new species described in the present paper keys out in couplet 3a, together with Ps. garthi (Barnard, 1952), but it differs from garthi in the following respects: (1) telson with short spines in garthi, versus very long spines in spinosus; (2) basis of pereiopod 7 with tall distoposterior point in garthi, versus a small point in spinosus; (3) palmar emargination of male gnathopod 2 deep in garthi, shallow in spinosus; (4) coxal plate 7 triangular and naked in garthi, rectangular and with 1 strong seta in spinosus; (5) posterior margin of basis of gnathopod 1 naked in garthi, with 2 long setae in spinosus; (6) basis of pereiopod 5 with overhanging posterodistal lobe in garthi, non-overhanging in spinosus; (7) distomedial peduncular spine of uropod 1 short in garthi, long in spinosus; (8) distal spines of rami of uropod 1 shorter in garthi than in spinosus.

Family Liljeborgiidae

Genus Idunella Sars, 1895

Idunella sketi Karaman, 1980
Karaman, 1980: 425-430, Figs. I-IV.

Material. - Sta. 91-22: 21 specimens; sta. 91-24: 42 specimens (for details about these stations, see under Cabogidiella littoralis).

Remarks. - This species, originally described from anchihaline cave waters of Bermuda, is common in interstitia of coarse sand and gravel in shallow waters of several places in the West Indies and in the Canary Islands. It is new to the Cape Verde Islands.

\section{ISOPODA}

Family Gnathostenetroididae

Genus Caecostenetroides Fresi \& Schiecke, 1968

Caecostenetroides mixtum n. sp.

(Figs. 7-9)

Material. - Sta. 91-24: 1 \% (holotype), 1 \& allotype, 53 paratypes (ZMA Is. 105.513); sta. 91-21: 22 paratypes (ZMA Is. 105.510); sta. 91-22: 14 paratypes (ZMA Is. 105.511); sta. 91-23: 5 paratypes (ZMA Is. 105.512). For more details about these stations, see under Cabogidiella littoralis.

Description. - Body length (cephalic frons to distal margin pleotelson) $3.5 \mathrm{~mm}$ (female paratype) or 3.3 mm (male holotype). Body (Fig. 7a) almost colourless, eye-less. Anterolateral corners of pereionites 1 to 6 with small spine.

Antenna 1 (Fig. 7c) 5-segmented; 1 long aesthetàsc on apex of segment 5 and 1 distolateral aesthetasc on segment 4 .

Antenna 2 (Figs. 7d, e): Small 1-segmented exopodite inserted on peduncle segment 3 ; flagellum 18- to 25-segmented.

Labrum (Fig. 7f) rounded. Labium (Fig. 7b) with many subapical setae.

Mandibles (Figs. $7 \mathrm{~g}, \mathrm{~h}$ ) with heavy incisor. Left mandible (Fig. 7g) with 3-dentate lacinia mobilis; 2 serrate and 4 smooth spines between incisor and molar; molar conical, with 3 subapical setae and tuft of setules; palp 3-segmented, segment 2 with 1 barbed, 1 smooth, and 2 smaller spines; segment 3 sickle-shaped with 10-15 small spinules on endal 


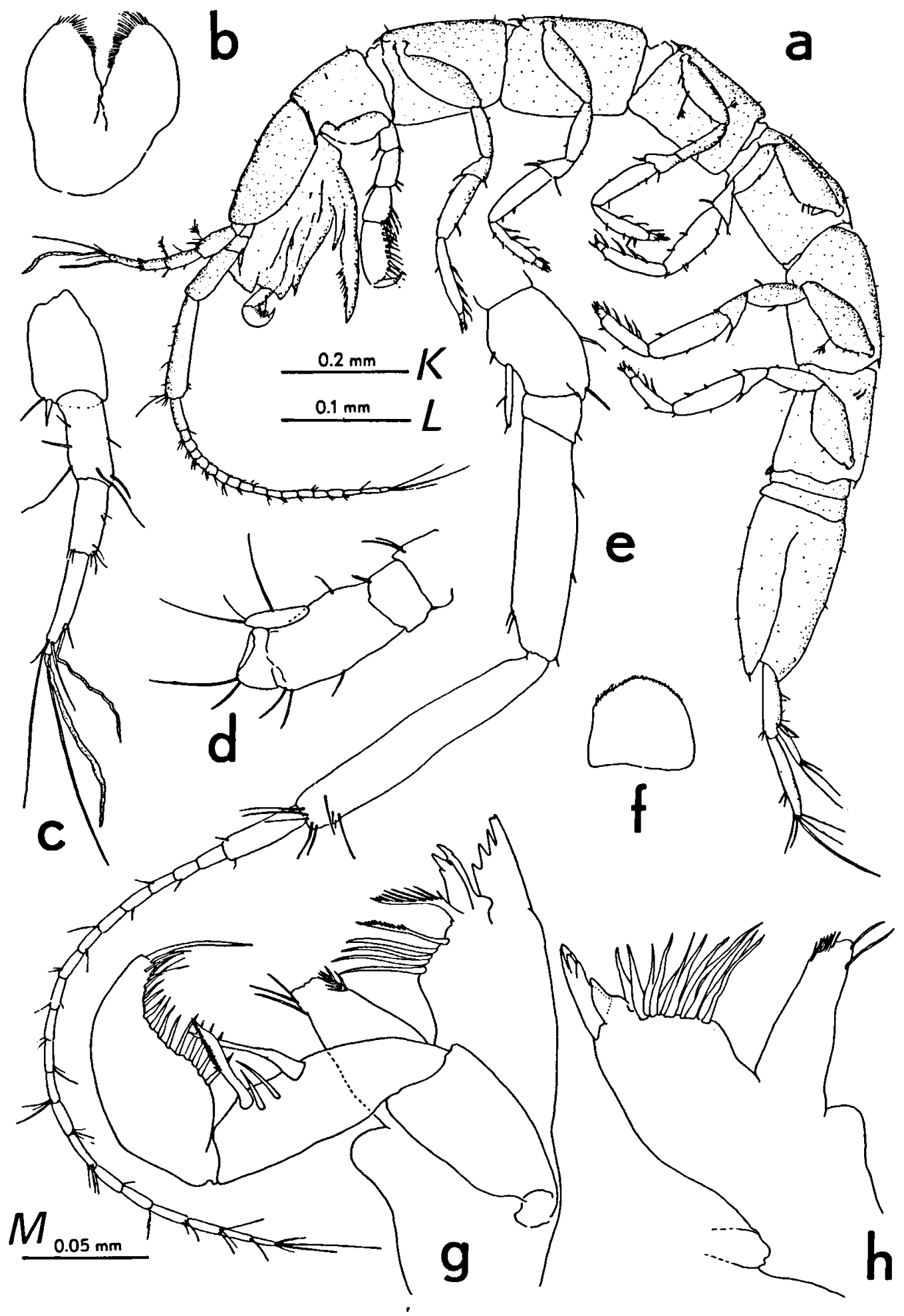

Fig. 7. Caecostenetroides mixtum n. sp. (a, ơ paratype, $2.5 \mathrm{~mm}$; d, $९$ allotype, $3.3 \mathrm{~mm}$; b-c, e-h, $\sigma$ holotype, $3.3 \mathrm{~mm}$ ): a, body, lateral (scale K); b, labium (L); c, antenna 1 (L); d, antenna 2 (L); e, peduncle of antenna 2 (L); f, labrum (L); g, left mandible (M); h, right mandible (M). 

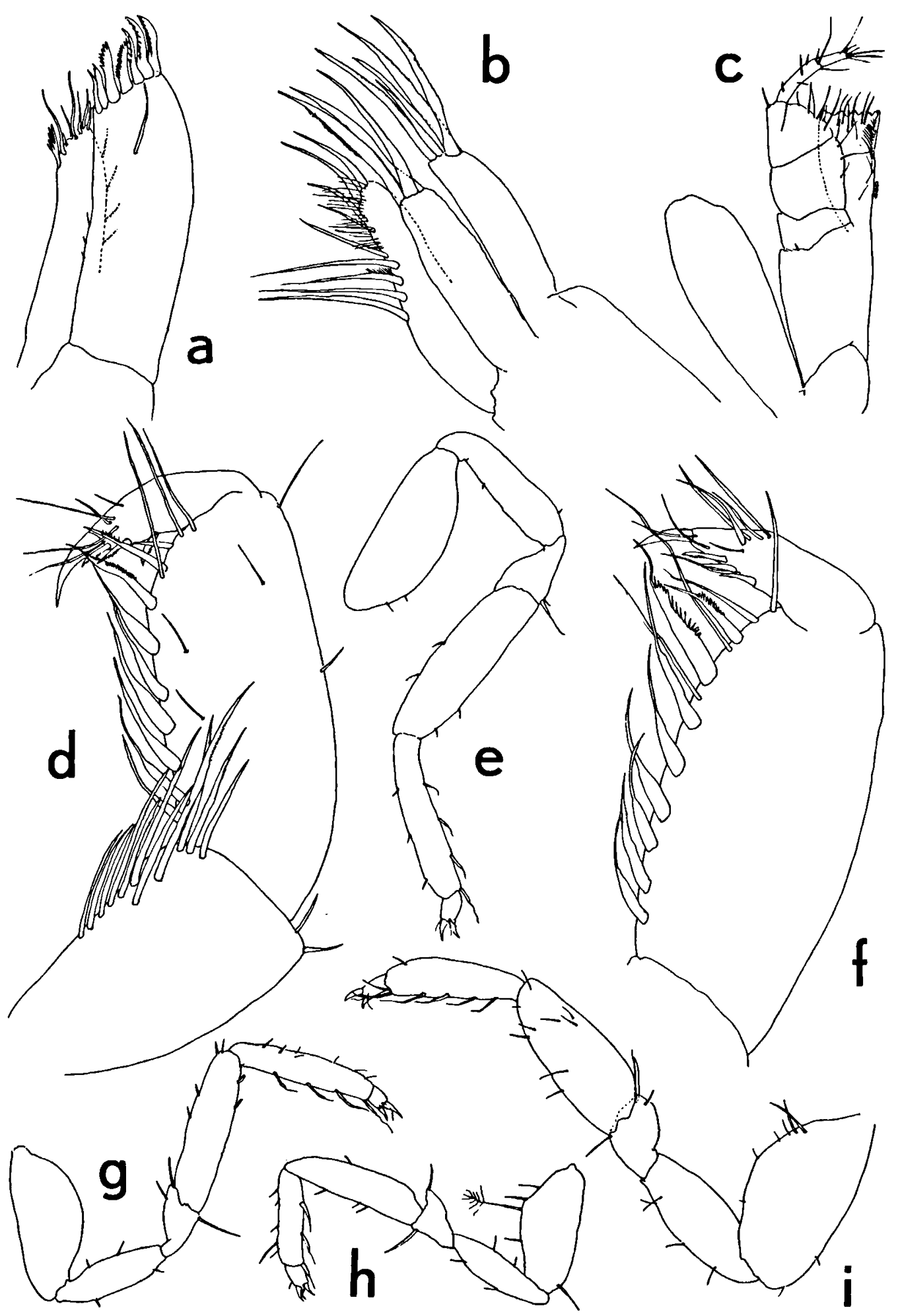

Fig. 8. Caecostenetroides mixtum n. sp. (a-c, o holotype, $3.3 \mathrm{~mm}$; d, i, o paratype, $2.7 \mathrm{~mm}$; e, $\&$ paratype, $3.2 \mathrm{~mm}$; f, $९$ allotype, $3.3 \mathrm{~mm} ; \mathrm{g}-\mathrm{h}$, on paratype, $2.5 \mathrm{~mm}$ ): a, maxilla 1 (scale M); b, maxilla $2(\mathrm{M})$; c, maxilliped (L); d, pereiopod 1 (L); e, pereiopod 2 (L); f, distal part of pereiopod 1 (M); g, pereiopod 3 (L); h, pereiopod 4 (L); i, pereiopod 5 (L). Scales on Fig. 7. 
margin and 1 strong apical spine. Right mandible (Fig. 7h) with 10-12 spines between incisor and molar; no lacinia observed.

Maxilla 1 (Fig. 8a): Outer lobe with 6-8 denticulate spines; inner lobe with several distal and subdistal setae and setules, and a small, toothed distomedial element.

Maxilla 2 (Fig. 8b) with 3 lobes: outer lobe with 5 , central lobe with 3 pennate spines, inner lobe with 9-11 distal and mediodistal setae, one of which barbed.

Maxilliped (Fig. 8c) with elongate-oval epipodite. Endite with straight medial margin, armed with several setules and 3 coupling hooks, opposing 3 hooks on the contralateral side; anterior margin truncate. Palp 5-segmented, segments 1 to 3 expanded, segments 4 and 5 narrow.

Pereiopod 1 (Figs. 8d, f): Carpus elongatetrapezoidal, ventrally with $4-5$ pectinate setae and 8-12 smooth setae. Propodus elongate-rectangular, twice as long as wide; ventral margin lined with 6 conical spines and 1 long palmar angle spine, latter finely serrate on inner margin and with thin extension at tip. Palmar margin slightly convex, with 2 spines, one of which serrate. Dactylus with 3 denticulate teeth on endal margin; unguis less than half as long as dactylus.

Pereiopods 2 to 7 (Figs. 8e, g-i; 9a-c) subsimilar. Propodus usually with 4 crooked spines on endal margin, sometimes with 2,3 , or 5; presence of plumose seta on inner margin of basis variable as well. Dactylus with 2 subequal claws, a sigmoid distal seta, and some smaller distal setules. Remaining setation rather irregular.

Pleonites (Figs. 7a, 9k): Two free pleonites, welldeveloped, not enclosed by pereionite 7 .

Pleopods: Pleopod 1 (Fig. 9e) present in $0^{\circ}$, lacking in $Q$; large and operculiform, deeply cleft, covering remaining pleopods. Pleopods 2 o' (Fig. 9f) separate, basipodite with 3 medial setae; exopodite 2-segmented, last segment with 1 short seta; endopodite segment 2 with bundle of vaguely pectinate "setae"; no longitudinal grooves observed along the segments. Pleopods 2 \% (Fig. 9d) fused, operculiform, with medioterminal notch and 4 setae. Pleopod 3 o (Fig. 9g) and $\%$ with 2-segmented exopodite and 1-segmented endopodite; endopo- dite with 3 plumose distal setae, exopodite with 2 setáe, 1 distal and 1 subdistal. Pleopod 4 o (Fig. 9h) and $\odot$ with 2 -segmented exopodite, bearing 3 plumose distal setae; endopodite with 1 distal plumose setule. Pleopod 5 o (Fig. 9i) and \& uniramous, unsegmented, with 1 short distal plumose seta.

Uropod (Fig. 9j): Peduncle and rami richly setose; exopodite about half as long as endopodite.

Marsupium consisting of large, overlapping translucent plates, devoid of setae, attached laterally to pereionites 2 to 5 . Genital papillae of male (Fig. 9k) protruding ventroproximally from pereionite 7.

No clear secondary sexual differences have been observed, except for the females being somewhat larger than the males, and of course in the pleopods 1 and 2.

Remarks. - Four species of Caecostenetroides are actually known: C. ischitanum Fresi \& Schiecke, 1968; C. nipponicum Nunomura, 1975, C. ruderalis Stock \& Vonk, 1990, and C. ascensionis Vonk \& Stock, 1991. Caecostenetroides mixtum n. sp. is closely related to $C$. ruderalis, from marine interstices of Tenerife (Canary Islands). The most important difference is no doubt that the second male pleopod does not resemble that of $C$. ruderalis, but that of two geographically more remote species, $C$. ascensionis and $C$. nipponicum (exopodite with short distal seta, instead of a long seta; endopodite with bunch of distal spines, instead of one large sigmoid spine). Other, less striking, differences pertain to (1) the first antenna, which bears 2 aesthetascs in C. mixtum, versus 1 in C. ruderalis; (2) the presence of anterolateral spines on the corners of the pereionites, absent in C. ruderalis; (3) absence of distal spiniform processes on the labium, versus presence in $C$. ruderalis; (4) more postincisor spines, several of them naked; (5) broad, smooth spines on propodal margin of pereiopod 1 , 3 instead of 4 endal spines on dactylus.

The presence of a second aesthetasc on antenna 1 is encountered also in $C$. ischitanum, from the Gulf of Naples, but not in the other species.

Etymology. - The specific name, mixtum, alludes 


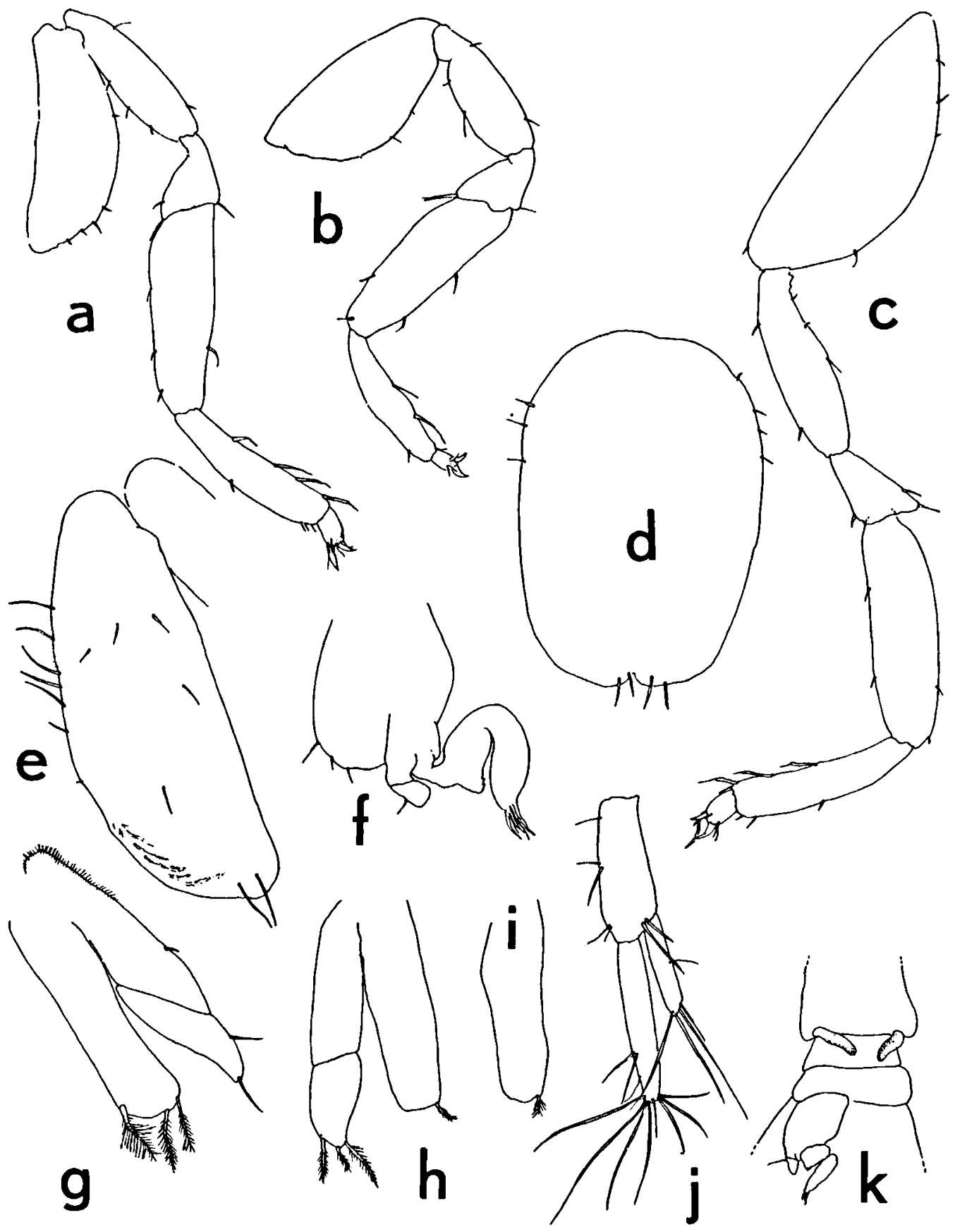

Fig. 9. Caecostenetroides mixtum n. sp. (a, c-d, o paratype, $3.2 \mathrm{~mm} ; \mathrm{b}, \sigma$ paratype $2.7 \mathrm{~mm} ; \mathrm{e}-\mathrm{f}, \sigma$ holotype $3.3 \mathrm{~mm} ; \mathrm{g}-\mathrm{j}, \sigma 0$ paratype, $2.5 \mathrm{~mm}$ ): a, pereiopod 6 (Scale L); b, pereiopod 7 (L); c, pereiopod 7 (L); d, pleopod 2 (L); e, pleopod 1 (L); f, pleopod 2 (L); g, pleopod 3 (L); h, pleopod 4 (L); i, pleopod 5 (L); j, uropod (L); k, pereionite 7 with genital papillae (pleopod 1 not shown) (K). Scales on Fig. 7. 
to the mixture of morphological traits of various species of Caecostenetroides.

\section{Acknowledgements}

The fieldwork for the present study was executed with the aid of a NATO (Brussels) Collaborative Research Grant, contract CRG 880011, the Treub Maatschappij (Amsterdam), and the Netherlands Foundation for the Advancement of Tropical Research (WOTRO, The Hague). We thank Mr. Kees Hazevoet, INIA, São Jorge dos Orgãos (Cabo Verde) for his assistance on the island of Santiago, and ETI (Amsterdam) for aid in computer logistics.

\section{References}

Barnard, J.L., 1952. A new species of amphipod from Lower California (genus Eriopisa). Pacific Sci., 6: 295-299.

Bou, C., 1975. Les méthodes de récolte dans les eaux souterraines interstitielles. Annls. Spéléol., 29(4): 611-619.

Coineau, N. \& J.H. Stock, 1986. Amphipoda, Bogidiellidae. In: L. Botosaneanu (ed.), Stygofauna mundi: 574-580 (E.J. Brill, Leiden).

Fresi, E. \& U. Schiecke, 1968. Caecostenetroides ischitanum (Isopoda, Parastenetriidae) - A new genus and species from the Bay of Naples. Pubbl. Staz. zool. Napoli, 36: 427-436.

Karaman, G.S., 1980. Revision of genus Idunella Sars with description of new species, I. Sketi, n. sp. (fam. Liljeborgiidae). Acta adriat., 21(2): 409-435.

Karaman, G.S., 1982. Critical remarks to the recent revisions of Bogidiella-group of genera with study of some taxa (fam. Gammaridae). Poljoprivreda i Sumarstvo, 28 (3/4) (“'1981"): 31-57.

Karaman, G.S., 1988. The new genus of the family Bogidiellidae (Gammaridea) from coastal seawater (mesopsammon) of Ita- ly, Aurobogidiella, n. gen. Poljoprivreda i Sumarstvo, 34(4): 93-105.

Nunomura, N., 1975. Marine Isopoda from the rocky shore of Osaka Bay, Middle Japan, 1. Bull. Osaka Mus. nat. Hist., 29: 15-35.

Noodt, W., 1965. Interstitielle Amphipoden der konvergenten Gattungen Ingolfiella und Pseudingolfiella n. gen. aus Südamerika. Crustaceana, 9(1): 17-30.

Ruffo, S., 1974. Nuovi Anfipodi interstiziali delle coste del Sud Africa. Atti Ist. Veneto Sci. Lett. Arti, (Cl. Sci. mat. nat.) 132: 399-419.

Ruffo, S., 1979. Descrizione di due nuovi Anfipodi anoftalmi dell'Iran e del Madagascar. Boll. Mus. civ. Stor. nat. Verona, 6: 419-440.

Stock, J.H., 1981. The taxonomy and zoogeography of the family Bogidiellidae (Crustacea, Amphipoda), with emphasis on the West Indian taxa. Bijdr. Dierk., 51(2): 345-374.

Stock, J.H., 1991. A new species of Psammogammarus (Amphipoda, Melitidae) from river alluvia in Luzon, Philippines. Stygologia, 7(4): 227-233.

Stock, J.H. \& E. Sánchez, 1987. Psammogammarus initialis n. sp., a new mediolittoral interstitial amphipod crustacean from Tenerife. Stygologia, 3(3): 264-277.

Stock, J.H. \& R. Vonk, 1990. Marine interstitial Isopoda Asellota of the superfamily Gnathostenetroidoidea. Cah. Biol. mar., 31: 5-24.

Stock, J.H. \& R. Vonk, 1991. Une espèce nouvelle de Dulzura, genre d'Amphipodes hadziö̈des connu jusqu'ici seulement de l'Indo-Pacifique, découverte aux îles du Cap Vert (Océan Atlantique). Cah. Biol. mar., 32: 477-486.

Vonk, R., 1990. Psammogammarus stocki n. sp. (Crustacea, Amphipoda, Melitidae) from beach interstitia on Tenerife. Bijdr. Dierk., 60(3/4): 271-276.

Vonk, R. \& J.H. Stock, 1991. Caecostenetroides ascensionis n. sp., a blind interstitial isopod (Asellota, Gnathostenetroidoidea) from Ascension island, South Atlantic. Trop. Zool., 4: 89-98.

Received: 22 August 1991 